\title{
Regulation of a truncated isoform of AMP-activated protein kinase $\alpha$ (AMPKa) in response to hypoxia in the muscle of Pacific oyster Crassostrea gigas
}

\author{
Eric Guévélou ${ }^{\mathrm{a}}$, Arnaud Huvet $^{\mathrm{a}}$, Rossana Sussarellu ${ }^{\mathrm{a}, \mathrm{b}}$, Massimo Milan ${ }^{\mathrm{c}}$, Ximing Guo ${ }^{\mathrm{d}}$, Li Li ${ }^{\mathrm{e}}$, \\ Guofan Zhang ${ }^{\mathrm{e}}$, Virgile Quillien ${ }^{\mathrm{a}}$, Jean-Yves Daniel ${ }^{\mathrm{a}}$, Claudie Quéré ${ }^{\mathrm{a}}$, Pierre Boudry $^{\mathrm{a}}$, \\ Charlotte Corporeau ${ }^{\text {a, }}$
}

\author{
a Ifremer, UMR 6539 LEMAR, Centre Bretagne Z.I. Pointe du Diable, 29280 Plouzané, France \\ ${ }^{\mathrm{b}}$ CNRS IUEM-UBO, UMR 6539 LEMAR. Place Nicolas Copernic, 29280 Plouzané, France \\ ${ }^{c}$ Department of Comparative Biomedicine and Food Science, University of Padova, Viale dell'Università 16, \\ Legnaro, Padua, Italy \\ d Haskin Shellfish Research Laboratory, Institute of Marine and Coastal Sciences, Rutgers, The State University \\ of New Jersey, 6959 Miller Avenue, Port Norris, NJ 08349, USA \\ e Institute of Oceanology, Chinese Academy of Sciences, No. 7 Nanhai road, Qingdao 266071, China
}

*: Corresponding author : Charlotte Corporeau, email address : charlotte.corporeau@ifremer.fr

\begin{abstract}
:
AMP-activated protein kinase $\alpha$ (AMPKa) is a key regulator of energy balance in many model species during hypoxia. In a marine bivalve, the Pacific oyster Crassostrea gigas, we analyzed the protein content of adductor muscle in response to hypoxia during $6 \mathrm{~h}$. In both smooth and striated muscles, the amount of full-length AMP-activated protein kinase a (AMPKa) remained unchanged during hypoxia. However, hypoxia induced a rapid and muscle-specific response concerning truncated isoforms of AMPKa. In the smooth muscle, a truncated isoform of AMPKa was increased from 1 to $6 \mathrm{~h}$ of hypoxia, and was linked with accumulation of AKT kinase, a key enzyme of the insulin signaling pathway which controls intracellular glucose metabolism. In this muscle, aerobic metabolism was maintained over the $6 \mathrm{~h}$ of hypoxia, as mitochondrial citrate synthase activity remained constant. In contrast, in striated muscle, hypoxia did not induce any significant modification of neither truncated AMPKa nor AKT protein content, and citrate synthase activity was altered after $6 \mathrm{~h}$ of hypoxia. Together, our results demonstrate that hypoxia response is specific to muscle type in Pacific oyster, and that truncated AMPKa and AKT proteins might be involved in maintaining aerobic metabolism in smooth muscle. Such regulation might occur in vivo during tidal intervals that cause up to $6 \mathrm{~h}$ of hypoxia.
\end{abstract}

Keywords: Marine bivalve ; Crassostrea gigas ; Hypoxia ; AMP-activated protein kinase ; Alternative splicing; Adductor muscle 


\section{Introduction}

Sessile benthic marine mollusks of the intertidal zone, such as the Pacific oyster Crassostrea gigas, are exposed to large changes in environmental conditions every day. Over the tidal cycle, temporal variation in environmental factors such as oxygen availability or food supply may be considerable (Newell 1979). Moreover, eutrophication may increase organic matter in the water column, reducing levels of available oxygen, which can lead to hypoxia and sometimes anoxia (Gray et al. 2002; Wu 2002). Sessile organisms cannot escape from unfavorable environmental conditions and must adapt to oxygen variation in their environment; therefore, they would be expected to be tolerant of oxygen deprivation. This context makes marine bivalves good model species to study mechanisms involved in oxygen deprivation response (Storey 1993).

Hypoxia is a key environmental condition that plays a role in changing energy management and resource utilization in bivalves. Bivalves can adapt filtration rate in response to hypoxia by changing either the ventilation rate over the gills or the duration of valve opening/closing (Tran et al. 2000). After prolonged hypoxia during 20 days, the oyster energetic metabolism is modified by a switch from the aerobic to the anaerobic ATP production pathway (Le Moullac et al. 2007a). The oxygen critical point threshold $\left(\mathrm{PcO}_{2}\right)$, at which oysters switch to anaerobic metabolism, was determined at approximately $3 \mathrm{mg} \mathrm{L}^{-1}$ of oxygen (close to $30 \%$ oxygen saturation), depending on water temperature (Le Moullac et al. 2007b). To identify pathways that are activated or altered in response to hypoxia, a transcriptomic study was conducted in C. gigas during long-term hypoxia of 20 days at $30 \%$ oxygen saturation (Sussarellu et al. 2010). In the digestive gland, the principal biological processes that were up- or down-regulated were respiration, energetic metabolism assessed by the respiratory chain compartment and antioxidant defense in response to oxidative stress observed during hypoxia and/or normoxic recovery (Sussarellu et al. 2010). In Crassostrea virginica, a compensatory increase in activities of two mitochondrial enzymes, citrate synthase and cytochrome c oxidase, was reported after two weeks of hypoxia, suggesting that this species has both a better tissue aerobic capacity to compensate for reduced oxygen availability and a lower sensitivity to hypoxia than C. gigas (Ivanina et al. 2011).

In vertebrates, the AMP-activated protein kinase (AMPK) signaling pathway has been described as the key system regulating energy balance in cells in hypoxic conditions (Hardie 2007). AMPK is an heterotrimeric kinase composed of a catalytic a-subunit and two regulatory subunits, $\beta$ and $\gamma$. Genes encoding the three subunits of AMPK are highly conserved among the eukaryotic species, including vertebrates, invertebrates, plants, fungi, and protozoa (Hardie 2003). In human, 2 or 3 genes encode each subunit, giving rise to 12 possible heterotrimeric combinations, and splice variants further increase the potential diversity of AMPK proteins (Towler and Hardie 2007).

In mammals, AMPK is activated by metabolic stresses such as glucose deprivation, oxidative phosphorylation, ischemia or lack of oxygen (Hardie 2008). A high cellular ratio of AMP/ATP triggers the phosphorylation and stimulation of AMPK kinase activity (Choi et al. 2001). AMPK activation is regulated at the post-translational level through phosphorylation and dephosphorylation. Many phosphorylation sites have been described in AMPK subunits $\alpha$ and $\beta$ (Hawley et al. 1996; Woods et al. 2003; Mitchelhill et al. 1997). In rat liver, the AMPKa threonine 172 site has been identified as the determinant and required phosphorylation site for stimulation of AMPK kinase activity (Neumann 2003; Hawley et al. 1996; Suter et al. 2006; Stapleton et al. 1996; Carling et al. 2011)).

Once activated by low energy status, AMPK activates ATP-producing catabolic pathways such as lipolysis, glycolysis and glucose uptake, and deactivates ATP-consuming anabolic pathways such as glycogen synthesis and lipogenesis (Hardie 2004). Activated AMPK can 
rapidly phosphorylate and activate a wide array of target key metabolic enzymes (Hardie 2004). Long-term effects of AMPK activity have also been demonstrated on the gene expression of several metabolic enzymes involved in glucose homeostasis (Viollet et al. 2003; Hardie 2003; Sato et al. 2011). Another signaling pathway linked to mammalian cell survival during energy deficiency in hypoxic conditions is the phosphatidyl inositol 3-kinases $(\mathrm{PI} 3 \mathrm{~K}) /$ protein kinase $\mathrm{B}(\mathrm{AKT})$ pathway, which regulates glucose metabolism and controls cell apoptosis (Kim et al. 2012; Parcellier et al. 2008; Alvarez-Tejado et al. 2001). The kinase AKT is activated by serine/threonine phosphorylation so as to increase glucose transport into cells to provide ATP to serve as fuel (Manning and Cantley 2007).

Few studies have investigated AMPK in mollusks or marine invertebrates, although AMPKa has been already described in a terrestrial pulmonate gastropod (Ramnanan et al. 2010), the brine shrimp, (Zhu et al. 2007), some crab species, lobster, one zooplankton species (Frederich et al. 2009; Jost et al. 2012) and a nemertean worm (Stricker 2011; Stricker et al. 2010). To date, only one study has characterized AMPKa threonine 172 phosphorylation in a marine invertebrate, the crab Cancer irroratus, subjected to oxygen depletion (Pinz et al. 2005). Up to date, no data are available on genes or AMPK protein subunits in oysters.

The main objectives of this study were to characterize the AMPKa isoforms in the Pacific oyster $C$. gigas and to define their potential regulation in the hypoxic response. The hypoxic response of oyster was explored in the adductor muscle, which is composed of smooth and striated muscle, by quantifying the protein content of AMPKa and AKT proteins using heterologous antibodies combined with citrate synthase activity measurement

\section{Material and methods}

\subsection{Biological material}

\subsubsection{Hypoxia conditioning and muscle sampling}

Oyster conditioning and sampling were performed as described in (Sussarellu et al. 2011). Briefly, one hundred and twenty wild Pacific oysters aged approximately 24 months were sampled during their sexual resting stage (January 2009) from an oyster farm in the Bay of Brest (Plougastel, France) and transported to the ORPHY laboratory facilities (UBO, Brest, France) where they were placed in eight $50 \mathrm{~L}$ tanks ( $\mathrm{n}=15$ oysters per tank) and acclimated for $12 \mathrm{~h}$ in fully oxygenated through-flowing seawater.

The oysters were then kept out of the water for $3 \mathrm{~h}$ air drying to simulate a low tide, before being re-immersed in sea water in 8 tanks. In four tanks, oysters were maintained under normoxic conditions for 6 hours in fully oxygenated through-flowing seawater (oxygen at 8.8 $\mathrm{mg} \mathrm{L}^{-1}, 100 \%$ oxygen saturation at $11^{\circ} \mathrm{C}, 34$ salinity). In four other tanks, hypoxic conditions were maintained for 6 hours by reducing oxygen down to $2.6 \mathrm{mg} \mathrm{L}^{-1}$ (30\% oxygen saturation at $11^{\circ} \mathrm{C}, 34$ salinity), using an oxygen depletion system as described by (Pichavant et al. 2000). Hypoxic oxygen concentrations were reached by bubbling nitrogen though seawater in a reservoir tank supplying the 4 rearing tanks. Surface gas exchanges in the experimental tanks were limited by positioning the water outflow below the water surface. Oxygen concentration in the tank was monitored regularly and adjusted when necessary to keep hypoxia level constant throughout the experiment. Water flow rates were 0.7 and $3.6 \mathrm{~L} \mathrm{~min}^{-1}$ under hypoxic and normoxic conditions, respectively. Water was collected in a reservoir, reoxygenated with electric pumps, filtered $(0.22 \mu \mathrm{m})$ and UV-treated, before being re-circulated through the system. Samples of 5 oysters were taken from each tank after 1, 3, and 6 hours. These oysters were opened and dissected: the two parts composing the adductor muscle 
(smooth and striated muscle) were separated, pooled $(n=5)$ and immediately frozen in liquid nitrogen. For each condition and sampling time (hypoxia and normoxia), 4 pools of 5 muscles (striated and smooth separately) were sampled, one for each tank. These pools were ground using a Dangoumeau homogenizer at $-180^{\circ} \mathrm{C}$ and stored at $-80^{\circ} \mathrm{C}$ for further analysis.

\subsubsection{Wild oyster tissue sampling}

To analyze a specific protein content in several oyster tissues, six wild Pacific oysters aged approximately thirty six months (live weight $59.5 \pm 10.5 \mathrm{~g}$ ) were collected during their sexual resting stage (January 2009) in the bay of Brest (Plougastel, France). The oysters were opened and their tissues rapidly dissected. The tissues sampled were mantle edge, digestive gland, mantle, palps, smooth muscle, striated muscle, heart, gills and visceral ganglia.

After dissection, specific tissues from several animals were pooled and immediately stored in liquid nitrogen for further utilization. For each tissues, 4 pools have been made of 4 oysters $(n=4)$. These pools were ground at $-180^{\circ} \mathrm{C}$ using a Dangoumeau homogenizer and stored at $-80^{\circ} \mathrm{C}$ for later analysis.

\subsection{Methods}

\subsubsection{Cloning of AMPKa isoforms}

Total RNA of striated muscle sampled from wild oyster was extracted using Extract-all (Eurobio), at a concentration of $50 \mathrm{mg}$ frozen powder $/ 1.5 \mathrm{ml}$ buffer. RNA samples were then treated with DNAse I (1 U/mg total RNA, Sigma) and RNA quality was assessed using RNA nano chips and Agilent RNA 6000 nano reagents (Agilent Technologies) according to manufacturer's instructions. RNA concentrations were measured at $260 \mathrm{~nm}$ using an ND1000 spectrophotometer (Nanodrop Technologies), with the conversion factor 1OD = $40 \mu \mathrm{g} / \mathrm{mL}$ RNA. From $2 \mu \mathrm{g}$ total RNA, RT-PCR amplifications were carried out as described in (Huvet et al. 2004).

Two primers were designed based on an ampka sequence extracted from a draft genome assembly covering the start and stop codons: Cg-ampko-Start (5'CGGAGAAGTCCTCCTCCTCT-3') and Cg-ampka-Stop (5'-CTATCTGGCCAGTGTGGTGA$\left.3^{\prime}\right)$. Putative ampka cDNAs were amplified using the corresponding primers pair via PCR with an annealing temperature of $45^{\circ} \mathrm{C}$ (protocol in (Bacca et al. 2005). The PCR products were electrophoresed on $1 \%(\mathrm{w} / \mathrm{v})$ agarose in $1 \mathrm{X}$ TAE buffer gels (TAE: Tris, acetic acid, $0.5 \mathrm{M}$ EDTA) and stained with ethidium bromide. Gel-extracted PCR products (QIAquick ${ }^{\circledR}$ Gel Extraction Kit, Qiagen) were cloned using the TOPO TA cloning kit vector (Invitrogen), plasmids were then purified (Nucleospin Plasmid DNA plasmid purification, MaschereyNagel), digested (restriction enzyme EcoR1) and sequenced (Beckman Coulter Genomics).

Homology searches were performed with the obtained DNA sequences using a BLASTX searches (Altschul et al. 1997). The DNA sequences were then converted into predicted amino acid sequences using the ExPASy translate tool (Gasteiger et al. 2003) and a multiple alignment was performed on selected sequences using CLUSTALW (Combet et al. 2000). Protein domain conservation was performed using ExPASy prosite (de Castro et al. 2006) and SMART (Schultz et al. 1998; Letunic et al. 2011). 


\subsubsection{Total protein extraction}

Total protein extracts were obtained from the tissues sampled in wild C. gigas oysters and from pools of striated and smooth muscle from the hypoxia and normoxia conditioned oysters, according to (Corporeau and Auffret 2003). To solubilize proteins, powdered tissues were homogenized in a lysis buffer containing phosphatase and protease inhibitors $(150 \mathrm{mM}$ $\mathrm{NaCl}, 10 \mathrm{mM}$ Tris, pH 7.4, $1 \mathrm{mM}$ EDTA, $1 \mathrm{mM}$ EGTA, 1\% Triton X-100, 0.5\% Igepal, $5 \mathrm{ml}$ phosphatase inhibitor cocktail II, 2 tablets Complete EDTA free protease inhibitor cocktail; $\mathrm{pH}$ 8.8 at $4^{\circ} \mathrm{C}$ ). Total protein extracts were then quantified using a DC protein assay (Biorad) and concentration was determined quantitatively using 96-well micro-plates (Nunc) and a microplate reader connected to KC4 v3 software (Bio-Tek Instruments, Inc).

\subsubsection{Citrate synthase activity in muscle}

Prior to quantification of citrate synthase activity in striated and smooth muscle, each protein lysate was adjusted to a final concentration of $3.5 \mathrm{mg} / \mathrm{ml}$ by adding lysis buffer. CS activity was measured in a medium containing $100 \mathrm{mM}$ Tris- $\mathrm{HCl} \mathrm{pH} 8,0.2 \mathrm{mM}$ acetyl coA, $0.1 \mathrm{mM}$ 5.5'-Dithio-bis(2-nitrobenzoic acid) (DTNB). The reaction was initiated by addition of $0.5 \mathrm{mM}$ oxaloacaetate (final concentration), in a total volume of $200 \mu \mathrm{l}$ and activity was measured for 10 minutes at room temperature at $412 \mathrm{~nm}\left(\varepsilon=13600 \mathrm{~L} \mathrm{~mol}^{-1} \mathrm{~cm}^{-1}\right)$.

\subsubsection{Western-blot analysis}

Prior to western-blot analysis, each protein lysate was adjusted to a final concentration of 5 $\mathrm{mg} / \mathrm{ml}$ by adding lysis buffer. Protein samples were then denatured by Laemmli solution $(0.6$ $\mathrm{M}$ Tris- $\mathrm{HCl}, 1 \mathrm{ml}$ glycerol, $10 \% \mathrm{w} / \mathrm{v}$ SDS, $0.5 \mathrm{ml} 0.1 \% \mathrm{w} / \mathrm{v}$ bromophenol blue, $0.5 \mathrm{ml} \beta-$ mercaptoethanol) and $90 \mu \mathrm{g}$ of each protein extract was loaded onto a $10 \%$ SDS polyacrylamide gel. Proteins were then transferred to a PVDF membrane (Biorad) for immunodetection on western blot. Immunodetection was performed with several heterologous antibodies directed against AMPKa that were validated for their cross-reactivity in C. gigas: Cell Signaling Technology (CST) technical services blasted the antigenic epitope sequence of heterologous anti-AMPKa antibodies against the genome of $\mathrm{C}$. gigas, very recently available (Zhang et al., Nature, 2012 (doi:10.1038/nature11413)), and demonstrated that only AMPKa protein of C. gigas could be recognized by these antibodies (Cell Signaling Technology; personal communication). Thus, immunodetection was performed with several anti- AMPKa antibodies (Ozyme, Cell Signaling Technology): a rabbit monoclonal antiAMPKa antibody directed against amino-terminal sequence of human AMPKa (dilution 1:1000; CST \# 2603), a rabbit monoclonal anti-AMPKa antibody directed against residues surrounding Lys40 of human AMPKa (dilution 1:1000; CST \# 5832), and a mouse monoclonal antibody directed against purified recombinant human AMPKa1 protein (dilution 1:1000; CST \# 2793). We also used a polyclonal anti-AKT antibody directed against carboxyterminal sequence of mouse Akt (dilution 1:1000; CST \# 9272). Blots were revealed using an HRP-linked secondary goat anti-rabbit or anti-mouse antibody (dilution 1:5000) and a HRP detection kit (Biorad). The amount of protein detected was quantified using MULTI-ANALYST software (Biorad), with the background signal removed. The value obtained is expressed in $\mathrm{OD} / \mathrm{mm}^{2}$ and represents the band intensity expressed as mean count per pixel multiplied by the band surface.

To ensure that identical amounts of total protein samples were loaded into the gels, membranes were dehybridized by incubation for $1 \mathrm{~h}$ at room temperature in dehybridizing

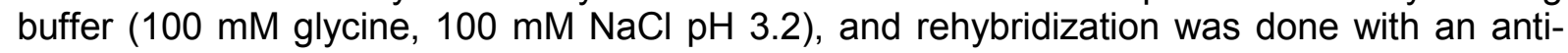
histone $\mathrm{H} 3$ antibody directed against the carboxy-terminal sequence of human histone $\mathrm{H} 3$ (dilution 1:5000;CST \# 9715;), as described in (Fabioux et al. 2009). 


\subsubsection{Statistical analysis}

Statgraphics software (StatPoint Technologies, Inc.) was used for all statistical analyses. For multiple comparisons within the same factor, we used the Fisher's least significant difference (LSD) procedure at the $95 \%$ confidence interval. Results are expressed as mean \pm standard deviation (SD).

\section{Results}

\subsection{Cloning and characterization of Crassostrea gigas ampka}

Using specific primers, we identified in the muscle of $C$. gigas three ampka clones of 1,212, 1,284 and 1,647 base pairs respectively. These sequences encoded three isoforms of AMPKa protein, named C. gigas_alpha_truncated 1 (GenBank accession number JX104212), C. gigas_alpha_truncated 2 (GenBank accession number JX104213) and C. gigas_alpha_like (GenBank accession number JX104214). As shown in figure 1, both truncated isoforms of AMPKa corresponded to alternative spliced variants of the ampka gene (GenBank accession number JX402632, Fig. 1). The 1,647 base pairs cDNA encoded an entire AMPKa protein of $62 \mathrm{kDa}$, and the 1,212 and 1,284 base pairs cDNAs encoded two truncated isoforms of 46 and $48 \mathrm{kDa}$, respectively (Fig. 2).

The three AMPKa sequences showed more than $70 \%$ conservation with AMPKa subunits in other species. The entire AMPKa protein of $62 \mathrm{kDa}$ contains the kinase domain, the binding domain for $\beta$ and $\gamma$ subunits, and the conservation of the threonine 172 active site and of two motifs surrounding threonine 172, (Asp-Phe-Gly and Ala-Pro-Glu) which is a characteristic phosphorylation site in kinase (Hardie et al. 1998) (Fig. 2). Blast results didn't reveal closer relationship to AMPKa isoforms characterized in vertebrate as $\alpha 1, \alpha 2$. Both truncated AMPKa isoforms of 46 and $48 \mathrm{kDa}$ were deleted in the kinase domain and lacked the threonine 172 phosphorylation site, although they conserved the C- terminal binding domain for $\beta$ and $Y$ subunits to form an heterotrimer (Towler and Hardie 2007) (Fig. 2). C. gigas_alpha_truncated 2 contained an additional group of 24 amino acids that was not characterized in the C. gigas_alpha_truncated 1 in the C-terminal region. All three C. gigas AMPK conserved the threonine 258 but missed the serine 485 phosphorylation sites (Fig. 2).

\subsection{Characterization of Crassostrea gigas akt.}

Among the C. gigas EST sequences in GigasDatabase (Fleury et al. 2009), we identified a sequence corresponding to the $C$. gigas akt gene (GenBank accession number FP004887). The corresponding partial amino acid sequence showed more than $60 \%$ conservation with akt2 of Atlantic salmon Salmo salar (FJ969488), akt of blackback land crab Gecarcinus lateralis (ADM87425) and akt2 of ferret Mustela putorius furo (AER94007). We also demonstrated the conservation of the pleckstrin homology $(\mathrm{PH})$ domain needed for anchorage of AKT to the cell membrane (Alessi et al. 1996) (Fig. 3).

\subsection{Tissue-specific detection of AMPKa isoforms protein}

All the anti- AMPKa antibodies we used could recognize two bands in western-blot, one at 62 $\mathrm{kDa}$ and one other at $48 \mathrm{kDa}$, but not at the same level of specificity, depending on the antibody we used. The band at $62 \mathrm{kDa}$ corresponded to the predicted size of the full-length AMPKa protein while the band at $48 \mathrm{kDa}$ corresponded to truncated isoforms of AMPKa. 
The anti-AMPKa antibody CST\#2793 (produced against a human recombinant AMPKa1 protein) recognized mainly the full-length $\mathrm{AMPKa}$ protein of $62 \mathrm{kDa}$ and very lightly recognized the truncated isoforms at $48 \mathrm{kDa}$ (very poor signal obtained after long exposure to ECL). This antibody allowed us to show that the entire AMPKa protein was expressed in all oyster tissues (data not shown).

In contrast, the anti-AMPKa antibody CST\#2603 (produced against a synthetic peptide derived from the amino-terminal sequence of human AMPK alpha) and the anti- AMPKa antibody CST\#5832 (produced against a synthetic peptide corresponding to residues surrounding lys 40 of human AMPKa) recognized very rapidly the truncated isoforms at 48 $\mathrm{kda}$ and very poorly the full-length AMPKa protein at $62 \mathrm{kDa}$ after a long ECL exposure. Using these antibodies, we were able to show that truncated AMPKa isoforms at $48 \mathrm{kDa}$ were specific for several tissues, mainly expressed in smooth and striated muscles (Fig. 4). Based on the calculated molecular weight of truncated AMPKa isoforms identified in C. gigas muscle, this band could be assigned to specific antibody recognition of either one variant or both variants of truncated AMPKa isoforms in C. gigas. We could not determine whether this band corresponded to a specific truncated isoform of 46 or $48 \mathrm{kDa}$ AMPKa, or both, since the band was large with rapid and high density and obtained in low resolution SDS-Page gels (10\% acrylamide). Figure 4 illustrates how C. gigas truncated AMPKa isoform was specifically expressed in five different tissues of oysters sampled at the sexual resting stage: the striated muscle had the highest density with $73.46 \mathrm{OD} / \mathrm{mm}^{2}$, followed by the smooth muscle with $42.20 \mathrm{OD} / \mathrm{mm}^{2}$. Much lower densities were observed for the mantle edge $(2.43$ $\left.\mathrm{OD} / \mathrm{mm}^{2}\right)$, heart $\left(0.34 \mathrm{OD} / \mathrm{mm}^{2}\right)$ and visceral ganglia $\left(0.07 \mathrm{OD} / \mathrm{mm}^{2}\right)$. Bands of even lower density were detected in the other tissues.

\subsection{AMPKa protein level during hypoxia}

Figure $5 \mathrm{~A}$ shows western-blot representative images obtained for the detection of the entire AMPKa protein at $62 \mathrm{kDa}$. Its quantification demonstrated that the entire AMPKa amount did not vary statistically during normoxia and hypoxia in both muscles (Two-Way ANOVA: $F=$ $1.55 ; p=0.2253$; data not shown).

In smooth muscle, the protein content of truncated AMPKa isoform at $48 \mathrm{kDa}$ significantly increased as early as $1 \mathrm{~h}$ after the hypoxia treatment started, compared with normoxia, and this increase was observed though the $6 \mathrm{~h}$ of hypoxia in the experiment (Two-Way ANOVA: $\mathrm{F}=8.92 ; p=0.0002$; Fig. $5 \mathrm{~B}$ ). In striated muscle, no significant difference was observed in the protein content of truncated AMPKa isoform between hypoxic and normoxic conditions (Two-Way ANOVA: F = 1.62; $p=0.2058$; Fig. $5 \mathrm{C}$ ).

\subsection{Citrate synthase activity during hypoxia}

In striated muscle, the activity of the citrate synthase was significantly modified (Two-Way ANOVA: $\mathrm{F}=3.75 ; p=0.00167$; Fig. $6 \mathrm{~B}$ ). This activity increased slightly after $3 \mathrm{~h}$ of hypoxia $(+12.3 \%)$ before significantly decreasing at $6 \mathrm{~h}(-22.5 \%)$ in comparison with normoxia, where it remained stable. In smooth muscle, no significant difference was measured in the activity of the citrate synthase either between treatments or between points in time within treatments (Two-Way ANOVA: $F=0.57 ; p=0.7206$; Fig. 6 A).

\subsection{AKT protein level during hypoxia}

To quantify AKT protein content in muscles, we used a heterologous monoclonal anti-AKT antibody. This antibody allowed us to detect a single band in SDS-PAGE at approximately 38 $\mathrm{kDa}$ (Fig. 7). In smooth muscle (Fig. $7 \mathrm{~A}$ ), this antibody showed that the AKT protein content was significantly (by 6.4 times) higher in the hypoxic condition than in the normoxic condition 
at $1 \mathrm{~h}$ (Two-Way ANOVA: $\mathrm{F}=3.00 ; p=0.0382$ ). A higher AKT protein content was maintained in hypoxia compared with normoxia after 3 and $6 \mathrm{~h}$ of the treatment $(1.5$ and 4.6 relative $\mathrm{OD} / \mathrm{mm}^{2}$, respectively), but these differences were not significant (Fig. $7 \mathrm{~A}$ ). In striated muscle (Fig. $7 \mathrm{~B}$ ), no significant difference was observed in AKT protein content between hypoxic and normoxic conditions (Two-Way ANOVA: $\mathrm{F}=0.82 ; p=0.5543$ ).

\section{Discussion}

\subsection{Crassostrea gigas AMPKa isoforms}

An important finding of the present study is that the entire AMPKa of $62 \mathrm{kDa}$ was ubiquitously expressed and that we identified two truncated AMPKa protein isoforms of 46 and $48 \mathrm{kDa}$ that were tissue-specifically expressed in C. gigas, mainly in smooth and striated muscles. Both truncated isoforms resulted from alternative splicing of the full-length ampka gene. Alternative splicing was already reported for some genes in C. gigas and the spliced variants may present a tissue-specific expression and a specific function (Rodet et al. 2008).

As demonstrated for genes involved in stress response in C. gigas (Kawabe and Yokoyama 2011a), we can hypothesize that hypoxia could have increase the alternative splicing leading to a rapid accumulation, as soon as $1 \mathrm{~h}$ after hypoxia, of truncated AMPKa in smooth muscle.

In all species, the size of the full-length AMPKa protein is around $62 \mathrm{kDa}$ (Apfeld et al. 2004; Beri et al. 1994; Carling et al. 1989; Yoshida et al. 1999; Zhu et al. 2007) as in oyster, where we demonstrated that the entire AMPKa had a molecular weight of $62 \mathrm{kDa}$. However, both truncated AMPKa were $33 \%$ shortened. They contained a truncated kinase domain and missed the threonine 172 phosphorylation site, important for AMPK activation in all species (Stapleton et al. 1996; Carling et al. 2011). Here we described the in vivo expression of these truncated isoforms of AMPKa in smooth and striated muscle as compared with other tissues.

In Artemia franciscana, one truncated isoform of AMPKa was found in addition to the entire AMPKa. In fact, the entire AMPKa2 is a 515-amino acid protein with a calculated molecular mass of approximately $58 \mathrm{kDa}$, and the truncated isoform results from a 244 base pairs deletion in its encoding mRNA that caused a frameshift, introducing a new translation stop codon that shortened the C-terminal of AMPKa2. This truncated protein had 313-amino acids with a calculated molecular mass of $36 \mathrm{kDa}$ (Zhu et al. 2007). Nevertheless, this truncated isoform of AMPKa kept its entire kinase domain and its activation through phosphorylation (Carling et al. 1989; Zhu et al. 2007). As reported in wormbase.org, in Caenorhabditis elegans, an AMPKa isoform named AAK-1b is truncated in its kinase domain and conserved its threonine 172 phosphorylation site but no functional data were obtained on this truncated kinase isoform (Yook et al. 2012).

\subsection{Muscle specific regulation of truncated AMPKa and AKT}

Crassostrea gigas inhabits the intertidal zone and shows high tolerance to stress conditions such as hypoxia and heat shock (Kawabe and Yokoyama 2011a, b). In C. gigas, the adductor muscle is one of the primary organs involved in responses to biotic or abiotic environmental variations, such as hypoxia (Le Moullac et al. 2007a; Samain and McCombie 2008). Valve closure is usually considered as a general stress response of marine bivalves to a wide variety of environmental stressors (Manley 1983; Akberali and Trueman 1985). Valve closure isolates the soft tissues from the external environment, which leads to a gradual decline of the oxygen in the mantle cavity water, and ultimately anoxia (Heinonen et 
al. 1997). In C. gigas, a prolonged $24 \mathrm{~h}$ period of hypoxia at $2 \mathrm{mg} \mathrm{L}^{-1}$ of oxygen was already reported to significantly reduce valve opening (Le Moullac 2008). At the cellular level, hypoxia was shown to slow down glycolysis (Le Moullac et al. 2007a) and to induce increased activity of the electron transfer system within the respiratory chain (Le Moullac et al. 2007b). In the context of the frequent environmental changes to which the species is exposed, energy supply to the adductor muscle could well be a priority at the organism level to ensure survival of the whole animal by keeping the valves closed more often/longer to protect the oyster against external stresses.

Indeed, in many species, the AMPK signaling pathway is involved in the coordination of anabolic and catabolic metabolic processes in various tissues, including cardiac and skeletal muscle, adipose tissue, pancreas and liver (Khan et al. 2006). In vertebrates, AMPK subunits have been reported in both striated muscle (Saha et al. 2000; Musi and Goodyear 2003) and smooth muscle, mainly cardiovascular smooth muscle (Ferri 2011; Sung et al. 2011), which led to the identification of AMPK as an important intracellular signaling pathway in these muscles.

In our study, we demonstrated a rapid and muscle-specific regulation of truncated AMPKa protein content by hypoxia in oysters while the amount of the entire AMPKa remained constant. Truncated AMPKa protein content was accumulated in smooth muscle after as little as $1 \mathrm{~h}$ of hypoxia and this continued throughout the $6 \mathrm{~h}$ of the treatment. We demonstrated that citrate synthase activity was maintained during $6 \mathrm{~h}$ of hypoxia in smooth muscle, while it slightly decreased in striated muscle. Mitochondrial citrate synthase is a key enzyme in aerobic energy production and is a useful indicator of general physiological status of $C$. gigas (Garcia-Esquivel et al. 2001; Garcia-Esquivel et al. 2002; Pernet et al. 2012). Citrate synthase activity reflects the mitochondrial oxidation capacity resulting from changes in mitochondrial number and activity (Tripathi and Verma 2004). In our experiment, as citrate synthase activity in smooth muscle did not show any difference between normoxic and hypoxic conditions, we suggest that its aerobic capacity was maintained during the $6 \mathrm{~h}$ of hypoxia, resulting in a higher metabolic performance than in the striated muscle. Since adductor muscle is not a storage tissue for glycogen in C. gigas (Berthelin et al. 2000), it needs to be supplied with glucose at a high rate to maintain an aerobic pathway of energy production. In the two oyster species $C$. gigas and $C$. virginica, the adductor muscle has been seen to use the PEPCK or PK pathway to allow high glycolysis in order to provide ATP for contractile activity (Greenway and Storey 1999; Le Moullac et al. 2007a). In adductor muscle of $C$. virginica, hypoxic conditions up-regulate mitochondrial enzymes, such as citrate synthase, in order to avoid metabolic depression and to provide better survival by minimizing physiological stress of oysters (Ivanina et al. 2011). Citrate synthase activity is an excellent marker of aerobic metabolism in vertebrates (Hanke et al. 2008) and invertebrates such as oysters (Ivanina et al. 2011; Pernet et al. 2012).

Our hypothesis is that in the smooth muscle of $C$. gigas, the increase of truncated AMPKa and AKT could be related to the maintaining of mitochondrial citrate synthase activity under short-term hypoxia to avoid metabolic depression. In many species, the role of oxygen stress on AMPK has been largely studied in relation to the fact that AMPK is viewed as a master regulator of energy (Hardie 2003). In general, AMPK switches on catabolic processes that provide alternative routes for generating ATP, such as glucose uptake, glycolysis, fatty acid oxidation or mitochondrial biogenesis (Hardie 2008). In rat skeletal muscle, conditions that cause reduction in cellular fuel status, including contraction, hypoxia, inhibition of oxidative phosphorylation, and hyperosmolar stress, have been demonstrated to increase AMPK activity and glucose transport (Hayashi et al. 2000). In cultures of rat skeletal muscle cells, AMPK can regulate glucose consumption (Hong et al. 2012). In skeletal muscle of mice, AMPK appears to be an obligate intermediate in the pathway to accelerate glucose uptake during hypoxia, to sustain ATP availability and cell survival in this tissue (Mu et al. 2001). Our experiment showed a rapid (from $1 \mathrm{~h}$ of hypoxia) and persistent (up to $6 \mathrm{~h}$ ) increase in AKT 
protein content in the smooth muscle concomitant with the increase in truncated AMPKa protein content, supporting the hypothesis of an increased glucose uptake in this muscle under hypoxic conditions. AKT is the key kinase, regulated by phosphorylation at threonine 308 and serine 473 , involved in the insulin signaling pathway, which regulates glucose metabolism, glucose entry into the cell and controls cell survival, especially under stressful conditions (Manning and Cantley 2007). Indeed, in rat skeletal muscle, AKT is activated in response to a high energy demand during prolonged exercise, and leads to enhance glucose transport and survival by increasing insulin-sensitivity (Funai et al. 2010).

Some elements of the insulin pathway have already been characterized in C. gigas: an insulin-related peptide cDNA (Hamano et al. 2005), an insulin-like receptor CIR (Gricourt et al. 2003) and Ras, Pten and p70S6K, three potential elements of the oyster insulin pathway (Jouaux et al. 2011). In vertebrates, hypoxia is known to activate the AKT cell survival pathway to maintain protection from apoptosis (Alvarez-Tejado et al. 2001; Kim et al. 2012). In vertebrate cell culture, the hypoxia-induced activation of AKT is observed even after 3-4 $\mathrm{h}$ of hypoxia but can be prevented by treatment with cycloheximide, suggesting that de novo protein synthesis is required (Alvarez-Tejado et al. 2001). AKT is also important for ischemiaprotection in human heart (Mullonkal and Toledo-Pereyra 2007). In mouse soleus muscle, glycogen content, AMPK activity and AKT activity did not differ significantly between hypoxia and control treatments, but insulin stimulation led AKT phosphorylation to be significantly higher in hypoxia than the control. This experiment emphasized the key role of insulin in AKT pathway under hypoxic conditions (Gamboa et al. 2011). In mouse cardiomyocytes, activation of both AKT and AMPK are important for maintaining glucose metabolism during oxidative stress (Horie et al. 2008), and a direct link was recently demonstrated between AMPK and AKT signaling pathways for promoting energy conservation and survival of skeletal muscle exposed to ischaemia (Chopra et al. 2011). In fact, evidence has been found for a direct cross-talk between AKT and AMPK that promotes cell survival in low energy status conditions under hypoxia in brain and heart in vertebrates (Kovacic et al. 2003; Bertrand et al. 2006). Such a relationship was also recently demonstrated in crucian carp heart (Stenslokken et al. 2008).

\subsection{Putative in vivo function for truncated AMPKa during hypoxia}

Many studies have shown that phosphorylation of threonine 172 is required for AMPK kinase activity to produce the downstream cellular effects of activated AMPK signaling (Neumann 2003; Hawley et al. 1996; Hardie et al. 1998). Indeed, under hypoxic conditions, AMPKa is regulated in the muscle at the post-translational level through threonine 172 phosphorylation, leading to AMPK kinase activation and downstream events in vertebrate models (Wadley et al. 2006). Due to its high conservation in C. gigas, we can assume that the kinase activity of the entire AMPKa protein of $62 \mathrm{kDa}$ could also be regulated through threonine 172 phosphorylation to act on downstream targets in both striated and smooth muscles. Indeed, in the liver of anoxia-tolerant goldfish (Carassius auratus) after 30 min of hypoxia (oxygen at $0.3 \mathrm{mg} \mathrm{L}^{-1}$ ), no changes in the quantity of total protein were observed, despite an increase in AMPK activity of nearly 5.5 fold (Jibb and Richards 2008). In contrast, in heart of crucian carp Carassius carassius after 10 days of hypoxia (oxygen at $0.3 \mathrm{mg} \mathrm{L}^{-1}$ ), no significantly changes in total protein and activity of AMPKa were observed compared with control conditions (Stenslokken et al. 2008).

As far as we know, our stduy is the first description of the accumulation of truncated AMPKa isoforms in response to hypoxia. As demonstrated, the truncated AMPKa did not contain neither the entire kinase domain nor the threonine 172 phosphorylation site. We thus can suppose that it might have another function than the entire AMPKa in response to hypoxia in the smooth muscle in C. gigas. In fact, (Noy et al. 2012) demonstrated that an in vivo truncated kinase, named Casein kinase II (CK2), that was deleted in its kinase domain (i.e. kinase-dead), can act as a regulator of the corresponding full-length CK2 function, by 
sequestration of the partners of full-length CK2. We can hypothesize that in oyster, the truncated AMPKa isoforms could serve as an in vivo modulator of the dowsntream AMPKa signaling during hypoxia in the smooth muscle. Indeed, since the truncated isoforms conserved the ligand binding domain for $\beta$ and $y$ subunits, these truncated AMPKa could have kept the ability to bind AMPKa ligands such as $\beta$ and $y$ subunits and/or downstream binding partners. Indeed, using a constructed mutant, (Ramanathan et al. 2010) demonstrated that a truncated human AMPKa in its kinase domain can conserve its binding capacity with $\beta$ and $y$ subunits. Moreover, the truncation of the kinase domain in human AMPKa rendered the heterotrimer less soluble, indicating that truncated AMPKa could exert its regulatory function through modulation of biochemical properties of AMPK complex and/or partners. Here we can conclude that the rapid increase in the protein amount of truncated AMPKa in smooth muscle could modulate the signaling pathway of the full-length AMPKa, and could have led to the protection of the citrate synthase activity during $6 \mathrm{~h}$ of hypoxia. Further investigations are needed to quantify the activity of the entire AMPKa response in presence of the truncated isoforms in C. gigas.

Response to hypoxia through the expression of truncated AMPKa was smooth musclespecific. Although both form part of the adductor muscle, smooth and striated muscles do not have the same metabolism and function. Indeed, in molluscs, the slow-acting smooth muscle can go into a catch state after contraction, and tension can be maintained for many hours with a small ATP turnover. In contrast, the quicker-acting muscle, usually striated to some extent, has phasic activity responsible for the rapid closure of the shell (Elliott and Bennett 1982). Here we showed that in oyster, the aerobic metabolism in the smooth muscle might be more protected against an environmental stress such as hypoxia and that the hypoxic response of smooth muscle seems to be mediated by the regulation of AMPKa isoforms.

\section{Conclusion}

In this manuscript, we showed that two truncated AMPKa isoforms, that lost the kinase domain and the determinant threonine 172 phosphorylation site, might play a role in the metabolic response during hypoxia in the smooth muscle of $C$. gigas. Our experiments suggested that the in vivo accumulation of truncated AMPKa, through alternative splicing, could serve as a modulator of the entire AMPKa response in order to maintain aerobic capacity and glucose homeostasis via AKT. Pacific oysters thus appeared as a good model to understand the environmental regulation of AMPKa signaling.

\section{Acknowledgments}

The present research project was supported by "Europole Mer" (www.europolemer.eu; project "OxyGenes") and by the ANR (project "Gametogenes" ANR-08-GENM-041) with collaboration supported National Basic Research Program of China (973 Program, no. 2010CB126401). Eric Guévélou was funded by Ifremer and a Région Bretagne doctoral grant.

The authors are grateful to Karine Pichavant of the ORPHY laboratory for logistic support, the organization of the experimental hypoxic system and for technical support during the animal conditioning. The authors are indebted to Chantal Cahu for advice and support. We thank Helen McCombie for her help with editing the English.

The authors declare that they have no conflict of interest. 


\section{References}

Akberali HB, Trueman ER (1985) Effects of Environmental-Stress on Marine Bivalve Mollusks. Advances in Marine Biology 22:101-198

Alessi DR, Andjelkovic M, Caudwell B, Cron P, Morrice N, Cohen P, Hemmings BA (1996) Mechanism of activation of protein kinase B by insulin and IGF-1. Embo J 15 (23):6541-6551

Altschul SF, Madden TL, Schaffer AA, Zhang J, Zhang Z, Miller W, Lipman DJ (1997) Gapped BLAST and PSI-BLAST: a new generation of protein database search programs. Nucleic acids research 25 (17):3389-3402

Alvarez-Tejado M, Naranjo-Suarez S, Jimenez C, Carrera AC, Landazuri MO, del Peso L (2001) Hypoxia induces the activation of the phosphatidylinositol 3-kinase/Akt cell survival pathway in PC12 cells: protective role in apoptosis. The Journal of biological chemistry 276 (25):22368-22374. doi:10.1074/jbc.M011688200

Apfeld J, O'Connor G, McDonagh T, DiStefano PS, Curtis R (2004) The AMP-activated protein kinase AAK-2 links energy levels and insulin-like signals to lifespan in $C$. elegans. Genes Dev 18 (24):3004-3009. doi:gad.1255404 [pii]

10.1101/gad.1255404

Bacca H, Huvet A, Fabioux C, Daniel J-Y, Delaporte M, Pouvreau S, Van Wormhoudt A, Moal J (2005) Molecular cloning and seasonal expression of oyster glycogen phosphorylase and glycogen synthase genes. Comp Biochem Physiol B Biochem Mol Biol 140 (4):635-646. doi:10.1016/j.cbpc.2005.01.005

Beri RK, Marley AE, See CG, Sopwith WF, Aguan K, Carling D, Scott J, Carey F (1994) Molecular cloning, expression and chromosomal localisation of human AMP-activated protein kinase. FEBS letters 356 (1):117-121

Berthelin CH, Kellner K, Mathieu M (2000) Storage metabolism in the Pacific oyster (Crassostrea gigas) in relation to summer mortalities and reproductive cycle (west coast of France). Comp Biochem Physiol B Biochem Mol Biol 125 (3):359-369

Bertrand L, Ginion A, Beauloye C, Hebert AD, Guigas B, Hue L, Vanoverschelde JL (2006) AMPK activation restores the stimulation of glucose uptake in an in vitro model of insulin-resistant cardiomyocytes via the activation of protein kinase B. Am J Physiol Heart Circ Physiol 291 (1):H239-250. doi:10.1152/ajpheart.01269.2005

Carling D, Clarke PR, Zammit VA, Hardie DG (1989) Purification and characterization of the AMP-activated protein kinase. Copurification of acetyl-CoA carboxylase kinase and 3hydroxy-3-methylglutaryl-CoA reductase kinase activities. European journal of biochemistry / FEBS 186 (1-2):129-136. doi:10.1111/j.1432-1033.1989.tb15186.x

Carling D, Mayer FV, Sanders MJ, Gamblin SJ (2011) AMP-activated protein kinase: nature's energy sensor. Nature chemical biology 7 (8):512-518. doi:10.1038/nchembio.610

Choi SL, Kim SJ, Lee KT, Kim J, Mu J, Birnbaum MJ, Soo Kim S, Ha J (2001) The regulation of AMP-activated protein kinase by $\mathrm{H}_{2} \mathrm{O}_{2}$. Biochem Biophys Res Commun 287 (1):9297. doi:10.1006/bbrc.2001.5544

Chopra I, Li HF, Wang H, Webster KA (2011) Phosphorylation of the insulin receptor by AMP-activated protein kinase (AMPK) promotes ligand-independent activation of the insulin signalling pathway in rodent muscle. Diabetologia 55 (3):783-794. doi:10.1007/s00125-011-2407-y

Combet C, Blanchet C, Geourjon C, Deleage G (2000) NPS@: network protein sequence analysis. Trends in Biochemical Sciences 25 (3):147-150. doi:10.1016/S09680004(99)01540-6

Corporeau C, Auffret M (2003) In situ hybridisation for flow cytometry: a molecular method for monitoring stress-gene expression in hemolymph cells of oysters. Aquatic Toxicology 64 (4):427-435. doi:10.1016/S0166-445X(03)00099-7

de Castro E, Sigrist CJ, Gattiker A, Bulliard V, Langendijk-Genevaux PS, Gasteiger E, Bairoch A, Hulo N (2006) ScanProsite: detection of PROSITE signature matches and 
ProRule-associated functional and structural residues in proteins. Nucleic acids research 34 (Web Server issue):362-365. doi:10.1093/nar/gkl124

Elliott A, Bennett PM (1982) Structure of the thick filaments in molluscan adductor muscle. Society of General Physiologists series 37:11-28

Fabioux C, Corporeau C, Quillien V, Favrel P, Huvet A (2009) In vivo RNA interference in oyster-vasa silencing inhibits germ cell development. FEBS journal 276 (9):25662573. doi:10.1111/j.1742-4658.2009.06982.x

Ferri N (2011) AMP-activated protein kinase and the control of smooth muscle cell hyperproliferation in vascular disease. Vascular pharmacology. doi:10.1016/j.vph.2011.10.003

Fleury E, Huvet A, Lelong C, de Lorgeril J, Boulo V, Gueguen Y, Bachere E, Tanguy A, Moraga D, Fabioux C, Lindeque P, Shaw J, Reinhardt R, Prunet P, Davey G, Lapegue S, Sauvage C, Corporeau C, Moal J, Gavory F, Wincker P, Moreews F, Klopp C, Mathieu M, Boudry P, Favrel P (2009) Generation and analysis of a 29,745 unique Expressed Sequence Tags from the Pacific oyster (Crassostrea gigas) assembled into a publicly accessible database: the GigasDatabase. BMC genomics 10:341. doi:10.1186/1471-2164-10-341

Frederich M, O'Rourke MR, Furey NB, Jost JA (2009) AMP-activated protein kinase (AMPK) in the rock crab, Cancer irroratus: an early indicator of temperature stress. J Exp Biol 212 (Pt 5):722-730. doi:10.1242/jeb.021998

Funai K, Schweitzer GG, Castorena CM, Kanzaki M, Cartee GD (2010) In vivo exercise followed by in vitro contraction additively elevates subsequent insulin-stimulated glucose transport by rat skeletal muscle. American journal of physiology Endocrinology and metabolism 298 (5):E999-1010. doi:10.1152/ajpendo.00758.2009

Gamboa JL, Garcia-Cazarin ML, Andrade FH (2011) Chronic hypoxia increases insulinstimulated glucose uptake in mouse soleus muscle. American Journal of PhysiologyRegulatory Integrative and Comparative Physiology 300 (1):R85-R91. doi:DOI 10.1152/ajpregu.00078.2010

Garcia-Esquivel Z, Bricelj VM, Felbeck H (2002) Metabolic depression and whole-body response to enforced starvation by Crassostrea gigas postlarvae. Comp Biochem Physiol A Mol Integr Physiol 133 (1):63-77. doi:10.1016/S1095-6433(02)00112-5

Garcia-Esquivel Z, Bricelj VM, Gonzalez-Gomez MA (2001) Physiological basis for energy demands and early postlarval mortality in the Pacific oyster, Crassostrea gigas. Journal of Experimental Marine Biology and Ecology 263 (1):77-103. doi:10.1016/S0022-0981(01)00300-8

Gasteiger E, Gattiker A, Hoogland C, Ivanyi I, Appel RD, Bairoch A (2003) ExPASy: The proteomics server for in-depth protein knowledge and analysis. Nucleic acids research 31 (13):3784-3788

Gray JS, Wu RSS, Or YY (2002) Effects of hypoxia and organic enrichment on the coastal marine environment. Marine Ecology-Progress Series 238:249-279. doi:10.3354/meps238249

Greenway SC, Storey KB (1999) The effect of prolonged anoxia on enzyme activities in oysters (Crassostrea virginica) at different seasons. Journal of Experimental Marine Biology and Ecology 242 (2):259-272. doi:10.1016/S0022-0981(99)00103-3

Gricourt L, Bonnec G, Boujard D, Mathieu M, Kellner K (2003) Insulin-like system and growth regulation in the Pacific oyster Crassostrea gigas: hrlGF-1 effect on protein synthesis of mantle edge cells and expression of an homologous insulin receptor-related receptor. General and Comparative Endocrinology 134 (1):44-56. doi:10.1016/s00166480(03)00217-x

Hamano K, Awaji M, Usuki H (2005) cDNA structure of an insulin-related peptide in the Pacific oyster and seasonal changes in the gene expression. J Endocrinol 187 (1):5567. doi:10.1677/joe.1.06284

Hanke N, Meissner JD, Scheibe RJ, Endeward V, Gros G, Kubis HP (2008) Metabolic transformation of rabbit skeletal muscle cells in primary culture in response to low 
glucose. Biochimica et biophysica acta 1783 (5):813-825. doi:S0167-4889(07)003278 [pii]

10.1016/j.bbamcr.2007.12.012

Hardie DG (2003) Management of cellular energy by the AMP-activated protein kinase system. FEBS letters 546 (1):113-120. doi:10.1016/s0014-5793(03)00560-x

Hardie DG (2004) The AMP-activated protein kinase pathway - new players upstream and downstream. J Cell Sci 117 (Pt 23):5479-5487. doi:10.1242/jcs.01540

Hardie DG (2007) AMP-activated/SNF1 protein kinases: conserved guardians of cellular energy. Nat Rev Mol Cell Bio 8 (10):774-785. doi:10.1038/Nrm2249

Hardie DG (2008) AMPK: a key regulator of energy balance in the single cell and the whole organism. International journal of obesity 32 Suppl 4:7-12. doi:10.1038/ijo.2008.116

Hardie DG, Carling D, Carlson M (1998) The AMP-activated/SNF1 protein kinase subfamily: metabolic sensors of the eukaryotic cell? Annual review of biochemistry 67:821-855. doi:10.1146/annurev.biochem.67.1.821

Hawley SA, Davison M, Woods A, Davies SP, Beri RK, Carling D, Hardie DG (1996) Characterization of the AMP-activated protein kinase kinase from rat liver and identification of threonine 172 as the major site at which it phosphorylates AMPactivated protein kinase. The Journal of biological chemistry 271 (44):27879-27887. doi:10.1074/jbc.271.44.27879

Hayashi T, Hirshman MF, Fujii N, Habinowski SA, Witters LA, Goodyear LJ (2000) Metabolic stress and altered glucose transport - Activation of AMP-activated protein kinase as a unifying coupling mechanism. Diabetes 49 (4):527-531. doi:10.2337/diabetes.49.4.527

Heinonen J, Kukkonen J, Penttinen OP, Holopainen IJ (1997) Effects of hypoxia on valveclosure time and bioaccumulation of 2,4,5-trichlorophenol by the freshwater clam Sphaerium corneum [L]. Ecotoxicology and environmental safety 36 (1):49-56. doi:10.1006/eesa.1996.1486

Hong NY, Cui ZG, Kang HK, Lee DH, Lee YK, Park DB (2012) p-Synephrine stimulates glucose consumption via AMPK in L6 skeletal muscle cells. Biochem Biophys Res Commun. doi:10.1016/j.bbrc.2012.01.085

Horie T, Ono K, Nagao K, Nishi H, Kinoshita M, Kawamura T, Wada H, Shimatsu A, Kita T, Hasegawa K (2008) Oxidative stress induces GLUT4 translocation by activation of P13-K/Akt and dual AMPK kinase in cardiac myocytes. Journal of Cellular Physiology 215 (3):733-742. doi:10.1002/Jcp.21353

Huvet A, Herpin A, Degremont L, Labreuche Y, Samain J-F, Cunningham C (2004) The identification of genes from the oyster Crassostrea gigas that are differentially expressed in progeny exhibiting opposed susceptibility to summer mortality. Gene 343 (1):211-220. doi:10.1016/j.gene.2004.09.008

Ivanina AV, Froelich B, Williams T, Sokolov EP, Oliver JD, Sokolova IM (2011) Interactive effects of cadmium and hypoxia on metabolic responses and bacterial loads of eastern oysters Crassostrea virginica Gmelin. Chemosphere 82 (3):377-389. doi:DOI 10.1016/j.chemosphere.2010.09.075

Jibb LA, Richards JG (2008) AMP-activated protein kinase activity during metabolic rate depression in the hypoxic goldfish, Carassius auratus. J Exp Biol 211 (Pt 19):31113122. doi:10.1242/jeb.019117

Jost JA, Podolski SM, Frederich M (2012) Enhancing thermal tolerance by eliminating the pejus range: a comparative study with three decapod crustaceans. Marine EcologyProgress Series 444:263-274. doi:Doi 10.3354/Meps09379

Jouaux A, Heude-Berthelin C, Sourdaine P, Blin JL, Mathieu M, Kellner K (2011) Identification of Ras, Pten and p70S6K homologs in the Pacific oyster Crassostrea gigas and diet control of insulin pathway. General and Comparative Endocrinology. doi:10.1016/j.ygcen.2011.12.008

Kawabe S, Yokoyama Y (2011a) Novel isoforms of heat shock transcription factor 1 are induced by hypoxia in the Pacific oyster Crassostrea gigas. J Exp Zool A Ecol Genet Physiol 315 (7):394-407. doi:10.1002/jez.685 
Kawabe S, Yokoyama Y (2011b) Role of hypoxia-Inducible factor alpha in response to hypoxia and heat shock in the Pacific oyster Crassostrea gigas. Marine biotechnology. doi:10.1007/s10126-011-9394-3

Khan T, Hixon JA, Stauffer JK, Lincoln E, Back TC, Brenner J, Lockett S, Nagashima K, Powell D, Wigginton JM (2006) Therapeutic modulation of Akt activity and antitumor efficacy of interleukin-12 against orthotopic murine neuroblastoma. Journal of the National Cancer Institute 98 (3):190-202. doi:10.1093/jnci/djj021

Kim TR, Cho EW, Paik SG, Kim IG (2012) Hypoxia-induced SM22alpha in A549 cells activates the IGF1R/PI3K/Akt pathway, conferring cellular resistance against chemoand radiation therapy. FEBS letters. doi:10.1016/j.febslet.2011.12.036

Kovacic S, Soltys CLM, Barr AJ, Shiojima I, Walsh K, Dyck JRB (2003) Akt activity negatively regulates phosphorylation of AMP-activated protein kinase in the heart. Journal of Biological Chemistry 278 (41):39422-39427. doi:DOI 10.1074/jbc.M305371200

Le Moullac G (2008) Adaptation du métabolisme respiratoire de l'huître creuse Crassostrea gigas. Thèse de doctorat Université de Bretagne Occidentale:161

Le Moullac G, Bacca H, Huvet A, Moal J, Pouvreau S, Van Wormhoudt A (2007a) Transcriptional regulation of pyruvate kinase and phosphoenolpyruvate carboxykinase in the adductor muscle of the oyster Crassostrea gigas during prolonged hypoxia. J Exp Zool A Ecol Genet Physiol 307 (7):371-382. doi:10.1002/jez.390

Le Moullac G, Quéau I, Le Souchu P, Pouvreau S, Moal J, Jean-René. LC, Samain J-F (2007b) Metabolic adjustments in the oyster Crassostrea gigas according to oxygen level and temperature. Marine Biology Research 3 (5):357-366. doi:10.1080/17451000701635128

Letunic I, Doerks T, Bork P (2011) SMART 7: recent updates to the protein domain annotation resource. Nucleic acids research. doi:10.1093/nar/gkr931

Manley AR (1983) The effects of copper on the behavior, respiration, filtration and ventilation activity of Mytilus Edulis. Journal of the Marine Biological Association of the United Kingdom 63 (1):205-222

Manning BD, Cantley LC (2007) AKT/PKB signaling: navigating downstream. Cell 129 (7):1261-1274. doi:10.1016/j.cell.2007.06.009

Mitchelhill KI, Michell BJ, House CM, Stapleton D, Dyck J, Gamble J, Ullrich C, Witters LA, Kemp BE (1997) Posttranslational modifications of the 5'-AMP-activated protein kinase beta1 subunit. The Journal of biological chemistry 272 (39):24475-24479. doi:10.1074/jbc.272.39.24475

Mu J, Brozinick JT, Jr., Valladares O, Bucan M, Birnbaum MJ (2001) A role for AMPactivated protein kinase in contraction- and hypoxia-regulated glucose transport in skeletal muscle. Molecular cell 7 (5):1085-1094. doi:10.1016/S1097-2765(01)00251-9

Mullonkal CJ, Toledo-Pereyra LH (2007) Akt in ischemia and reperfusion. Journal of investigative surgery : the official journal of the Academy of Surgical Research 20 (3):195-203. doi:10.1080/08941930701366471

Musi N, Goodyear LJ (2003) AMP-activated protein kinase and muscle glucose uptake. Acta physiologica Scandinavica 178 (4):337-345. doi:10.1046/j.1365-201X.2003.01168.x

Neumann D (2003) Mammalian AMP-activated protein kinase: functional, heterotrimeric complexes by co-expression of subunits in Escherichia coli. Protein Expression and Purification 30 (2):230-237. doi:10.1016/s1046-5928(03)00126-8

Newell RC (1979) Biology of Intertidal Animals. Marine Ecological Surveys Ltd:781

Noy P, Sawasdichai A, Jayaraman PS, Gaston K (2012) Protein kinase CK2 inactivates $\mathrm{PRH} /$ Hhex using multiple mechanisms to de-repress VEGF-signalling genes and promote cell survival. Nucleic acids research. doi:gks687 [pii]

10.1093/nar/gks687

Parcellier A, Tintignac LA, Zhuravleva E, Hemmings BA (2008) PKB and the mitochondria: AKTing on apoptosis. Cellular signalling 20 (1):21-30. doi:10.1016/j.cellsig.2007.07.010 
Pernet F, Barret J, Gall PL, Corporeau C, Dégremont L, Lagarde F, Pépin JF, Keck N (2012) Mass mortalities of Pacific oysters Crassostrea gigas reflect infectious diseases and vary with farming practises in the Thau lagoon. Aquaculture Environement Interactions. doi:10.3354/aei00041

Pichavant K, Person-Le-Ruyet J, Le Bayon N, Sévère A, Le Roux A, Quéméner L, Maxime V, Nonnotte G, Boeuf G (2000) Effects of hypoxia on growth and metabolism of juvenile turbot. Aquaculture 188 (1-2):103-114. doi:10.1016/s0044-8486(00)00316-1

Pinz I, Perry DJ, Frederich M (2005) Activation of 5'-AMP activated protein kinase during anaerobiosis in the rock crab, Cancer irroratus. Bulletin of the Mount Desert Island Biological Laboratory 44:31-32

Ramanathan L, Sheth PR, Ogas P, Xiao L, Le HV (2010) Purification and characterization of truncated human AMPK alpha 2 beta 2 gamma 3 heterotrimer from baculovirusinfected insect cells. Protein Expression and Purification 70 (1):13-22. doi:S10465928(09)00255-1 [pii]

10.1016/j.pep.2009.10.007

Ramnanan CJ, McMullen DC, Groom AG, Storey KB (2010) The regulation of AMPK signaling in a natural state of profound metabolic rate depression. Molecular and cellular biochemistry 335 (1-2):91-105. doi:10.1007/s11010-009-0246-7

Rodet F, Lelong C, Dubos MP, Favrel P (2008) Alternative splicing of a single precursor mRNA generates two subtypes of Gonadotropin-Releasing Hormone receptor orthologues and their variants in the bivalve mollusc Crassostrea gigas. Gene 414 (12):1-9. doi:S0378-1119(08)00051-6 [pii]

10.1016/j.gene.2008.01.022

Saha AK, Schwarsin AJ, Roduit R, Masse F, Kaushik V, Tornheim K, Prentki M, Ruderman NB (2000) Activation of malonyl-CoA decarboxylase in rat skeletal muscle by contraction and the AMP-activated protein kinase activator 5-aminoimidazole-4carboxamide-1-beta -D-ribofuranoside. The Journal of biological chemistry 275 (32):24279-24283. doi:10.1074/jbc.C000291200

Samain J-F, McCombie H (2008) Summer mortality of Pacific oyster Crassostrea gigas. The Morest Project. Edition Ifremer Quae

Sato T, Toyoshima A, Hiraki T, Ohta Y, Katayama K, Arai T, Tazaki H (2011) Effects of metformin on plasma concentrations of glucose and mannose, G6Pase and PEPCK activity, and mRNA expression in the liver and kidney of chickens. Br Poult Sci 52 (2):273-277. doi:10.1080/00071668.2011.560595

Schultz J, Milpetz F, Bork P, Ponting CP (1998) SMART, a simple modular architecture research tool: identification of signaling domains. Proceedings of the National Academy of Sciences of the United States of America 95 (11):5857-5864

Stapleton D, Mitchelhill KI, Gao G, Widmer J, Michell BJ, Teh T, House CM, Fernandez CS, Cox T, Witters LA, Kemp BE (1996) Mammalian AMP-activated protein kinase subfamily. The Journal of biological chemistry 271 (2):611-614

Stenslokken KO, Ellefsen S, Stecyk JA, Dahl MB, Nilsson GE, Vaage J (2008) Differential regulation of AMP-activated kinase and AKT kinase in response to oxygen availability in crucian carp (Carassius carassius). American journal of physiology Regulatory, integrative and comparative physiology 295 (6):1803-1814. doi:10.1152/ajpregu.90590.2008

Storey KB (1993) Molecular mechanisms of metabolic arrest in molluscs. In Surviving Hypoxia: Mechanisms of Control and Adaptation. CRC press:253-269

Stricker SA (2011) Potential upstream regulators and downstream targets of AMP-activated kinase signaling during oocyte maturation in a marine worm. Reproduction 142 (1):29-39. doi:Doi 10.1530/Rep-10-0509

Stricker SA, Swiderek L, Nguyen T (2010) Stimulators of AMP-activated kinase (AMPK) inhibit seawater- but not CAMP-induced oocyte maturation in a marine worm: Implications for interactions between cAMP and AMPK signaling. Mol Reprod Dev 77 (6):497-510. doi:10.1002/mrd.21177 
Sung JY, Woo CH, Kang YJ, Lee KY, Choi HC (2011) AMPK induces vascular smooth muscle cell senescence via LKB1 dependent pathway. Biochem Biophys Res Commun 413 (1):143-148. doi:10.1016/j.bbrc.2011.08.071

Sussarellu R, Fabioux C, Le Goic N, Lambert C, Soudant P, Moraga D (2011) Molecular and cellular response to short-term oxygen variations in the Pacific oyster Crassostrea gigas. Journal of Experimental Marine Biology and Ecology 412:87-95. doi:10.1016/j.jembe.2011.11.007

Sussarellu R, Fabioux C, Le Moullac G, Fleury E, Moraga D (2010) Transcriptomic response of the Pacific oyster Crassostrea gigas to hypoxia. Marine genomics 3 (3-4):133-143. doi:10.1016/j.margen.2010.08.005

Suter M, Riek U, Tuerk R, Schlattner U, Wallimann T, Neumann D (2006) Dissecting the role of 5'-AMP for allosteric stimulation, activation, and deactivation of AMP-activated protein kinase. The Journal of biological chemistry 281 (43):32207-32216. doi:10.1074/jbc.M606357200

Towler MC, Hardie DG (2007) AMP-activated protein kinase in metabolic control and insulin signaling. Circulation research $100 \quad$ (3):328-341. doi:10.1161/01.RES.0000256090.42690.05

Tran D, Boudou A, Massabuau JC (2000) Mechanism for maintaining oxygen consumption under varying oxygenation levels in the freshwater clam Corbicula fluminea. Can $\mathrm{J}$ Zool 78 (11):2027-2036. doi:10.1139/cjz-78-11-2027

Tripathi G, Verma P (2004) Sex-specific metabolic changes in the annual reproductive cycle of a freshwater catfish. Comp Biochem Physiol B Biochem Mol Biol 137 (1):101-106. doi:10.1016/j.cbpc.2003.10.005

Viollet B, Andreelli F, Jorgensen SB, Perrin C, Flamez D, Mu J, Wojtaszewski JF, Schuit FC, Birnbaum M, Richter E, Burcelin R, Vaulont S (2003) Physiological role of AMPactivated protein kinase (AMPK): insights from knockout mouse models. Biochem Soc Trans 31 (Pt 1):216-219. doi:10.1042/

Wadley GD, Lee-Young RS, Canny BJ, Wasuntarawat C, Chen ZP, Hargreaves M, Kemp BE, McConell GK (2006) Effect of exercise intensity and hypoxia on skeletal muscle AMPK signaling and substrate metabolism in humans. American journal of physiology Endocrinology and metabolism 290 (4):E694-702. doi:10.1152/ajpendo.00464.2005

Woods A, Vertommen D, Neumann D, Turk R, Bayliss J, Schlattner U, Wallimann T, Carling D, Rider MH (2003) Identification of phosphorylation sites in AMP-activated protein kinase (AMPK) for upstream AMPK kinases and study of their roles by site-directed mutagenesis. The Journal of biological chemistry 278 (31):28434-28442. doi:10.1074/jbc.M303946200

Wu RSS (2002) Hypoxia: from molecular responses to ecosystem responses. Marine Pollution Bulletin 45 (1-12):35-45. doi:10.1016/S0025-326X(02)00061-9

Yook K, Harris TW, Bieri T, Cabunoc A, Chan J, Chen WJ, Davis P, de la Cruz N, Duong A, Fang R, Ganesan U, Grove C, Howe K, Kadam S, Kishore R, Lee R, Li Y, Muller HM, Nakamura C, Nash B, Ozersky P, Paulini M, Raciti D, Rangarajan A, Schindelman G, Shi X, Schwarz EM, Ann Tuli M, Van Auken K, Wang D, Wang X, Williams G, Hodgkin J, Berriman M, Durbin R, Kersey P, Spieth J, Stein L, Sternberg PW (2012) WormBase 2012: more genomes, more data, new website. Nucleic acids research 40 (Database issue):735-741. doi:gkr954 [pii]

10.1093/nar/gkr954

Yoshida EN, Benkel BF, Fong Y, Hickey DA (1999) Sequence and phylogenetic analysis of the SNF4/AMPK gamma subunit gene from Drosophila melanogaster. Genome 42 (6):1077-1087

Zhu XJ, Feng CZ, Dai ZM, Zhang RC, Yang WJ (2007) AMPK alpha subunit gene characterization in Artemia and expression during development and in response to stress. Stress 10 (1):53-63. doi:10.1080/10253890601130773 


\section{Figures}

Figure 1: Diagram representing the intron-exon structure of the C. gigas ampk alpha gene (GenBank accession number JX402632) and the three AMPK mRNAs obtained by alternative splicing of exons. AMPK alpha_like: GenBank accession number JX104214. AMPK alpha_truncated 1: GenBank accession number JX104212. AMPK alpha_truncated 2: GenBank accession number JX104213.

AMPK alpha gene

Ex1 Ex2 Ex3 Ex4 Ex5 Ex6 Ex7 Ex8 Ex9 Ex10 Ex11 Ex12 Ex13 Ex14 Ex15 Ex16 Ex17 Ex18 Ex19 Ex20 
Figure 2: Amino acid alignment of Crassostrea gigas AMPK alpha_Truncated 1 (GenBank accession number JX104212), AMPK alpha_Truncated 2 (GenBank accession number JX104213), with the full-length AMPK_alpha_like (GenBank accession number JX104214), Homo sapiens AMPK $\alpha 1$ and $\alpha 2$ (NM006251 and AAH69823). Sequence conservation is indicated in red for complete conservation among the compared species, in green for strong similarity, in blue for weak similarity and black where there is no conservation. Red, blue and orange arrows: Threonine 172,Threonine 258 and Serine 485 phosphorylation sites, respectively. Green squares: characteristic motifs surrounding the threonine 172 site in kinase (Asp-Phe-Gly and Ala-Pro-Glu). Orange square: binding domain for $\beta$ and $y$ subunits. "Prim.cons" line contains the consensus sequence (the most common amino acid at position). In case of a tie between two amino acid frequencies, a number is reported in this line.

Cgigas_alpha_truneated1 Cgigas_alpha_Truncated Cgigas_alpha_like Komo napiens 1 Momo_sapieng?

Prim.eons

Cgigas_alpha_Truncated Cgigas_alpha_ Iruneated? Cgigan_alpha_aike Komo sapiens 1 Homo_sapiens2

Prim.cons

Cgigan_alpha_Truneated Cgigas_alpha_Iruncateda Cgigas_alpha_like Homo gapiens? Komo_sapiens?

Prim, cons

Cgigas alpha Iruneated Cgigas alpha Truneated2 Cgigas_alpha_like romo apiens? Moms

Prim, eons

Cqigas_alpha_truncated? Cgigas_alpha_Iruneated Cgigan_alpha_like Cgiges alpha Homongapieng

Prim. sons.

Cgigas_alpha_Iruneased Cgigas_alpha_zruncated Cgigas alpha like Komo apiens 1 Homo-opien

Drim,eons

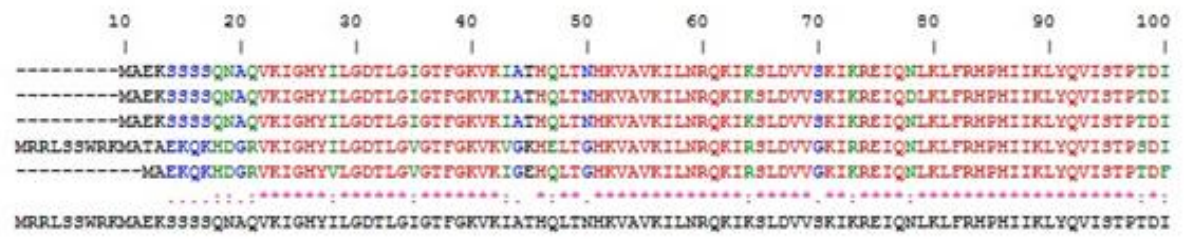

\begin{tabular}{|c|c|c|c|c|c|c|c|c|}
\hline 110 & 120 & 130 & 140 & 150 & 160 & 170 & 180 & 190 \\
\hline 1 & I & 1 & 1 & 1 & I & 1 & 1 & I \\
\hline
\end{tabular}

nonarvagGetro

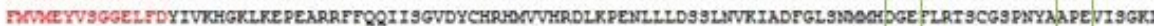
nCר:

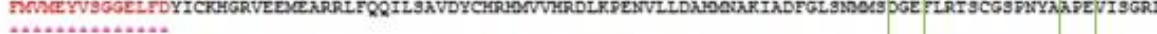

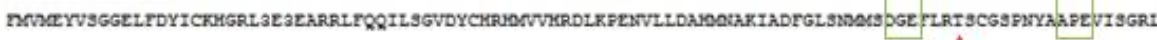

$\begin{array}{rrrrrrrrrrr}210 & 220 & 230 & 240 & 250 & 260 & 270 & 280 & 4 & 290 & 300 \\ 1 & 1 & 1 & 1 & 1 & 1 & 1 & 1 & 1\end{array}$

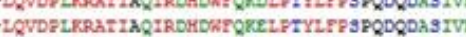

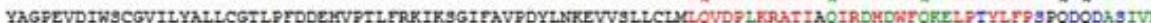
YATEVWDTW9OVIL

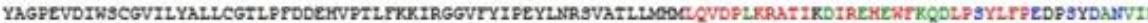

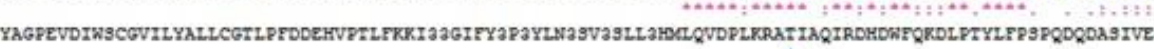

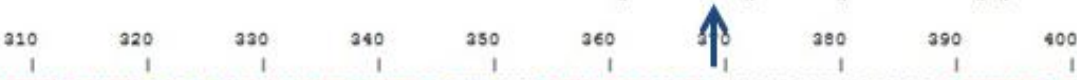

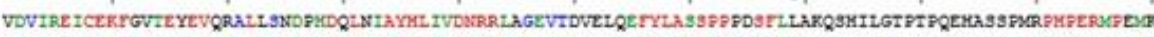

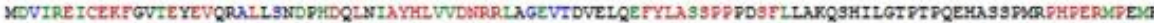

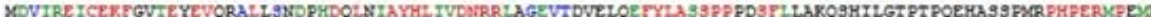

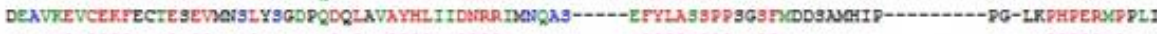

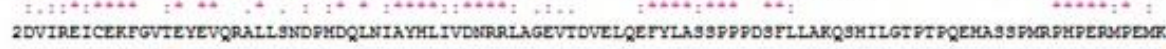

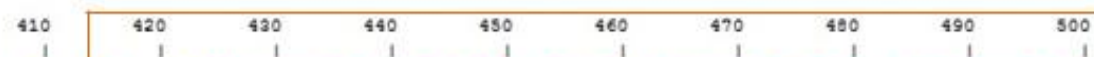

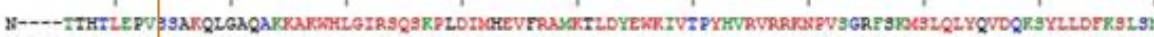

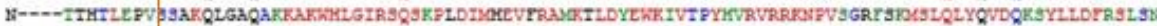

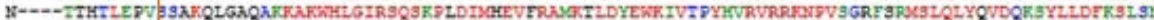
AETPRARYTI OE

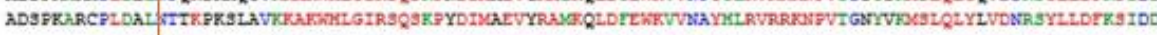
.

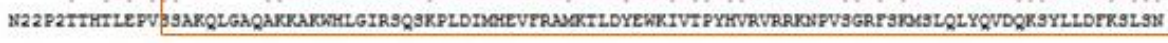

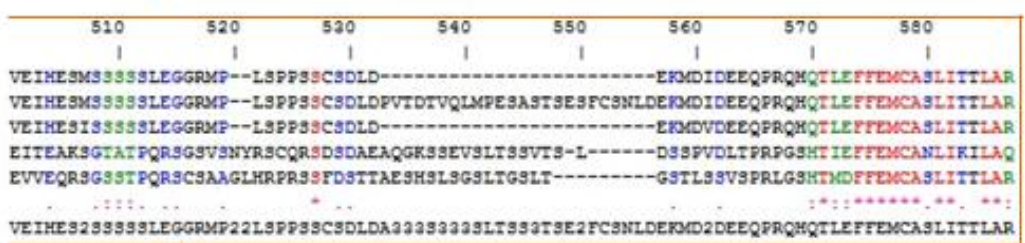


Figure 3: Amino acid alignment of Crassostrea gigas AKT C. gigas (GenBank accession number FP004887), AKT2 of Atlantic salmon Salmo salar Ssalar2 (GenBank accession number FJ969488), AKT of blackback land crab Gecarcinus lateralis Glateralis (GenBank accession number ADM87425), AKT3 of Homo sapiens Hsapiens3 (GenBank accession number BC121154) and AKT2 of Ferret Mustela putorius furo Mputorius3 (GenBank accession number AER94007). Sequence conservation is indicated in red for complete conservation among the compared species, in green for strong similarity, in blue for weak similarity, and in black where there is no conservation. Red square: pleckstrin homology $(\mathrm{PH})$ domain. "Prim.cons" line contains the consensus sequence (the most common amino acid at position). In case of a tie between two amino acid frequencies, a number is reported in this line.

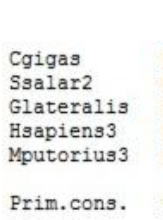

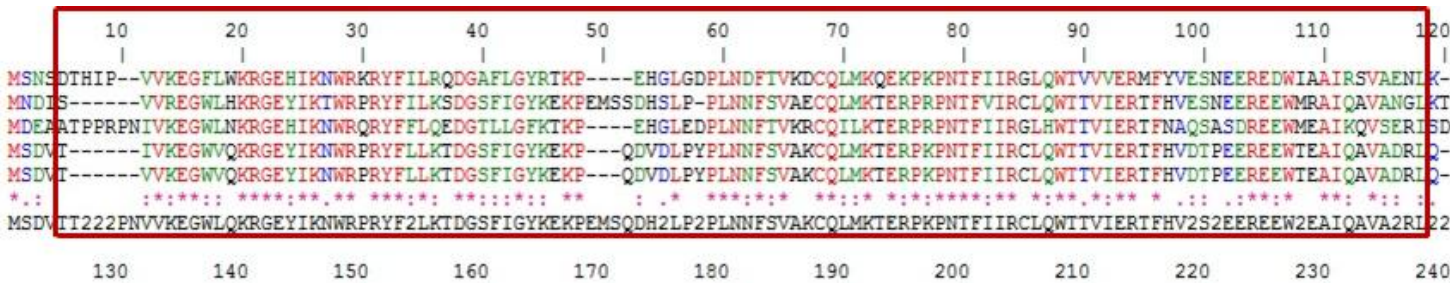

Prim.cons.

-----RVEEAPMDITFGSPSDCSGMEE---MEVAMSKSRNKVTVSDFDYLKLIGKGTFGKVILVKEKATGMYYAMKILRKEVITAKDEVAHTVTESRVLONTRHPFLTTLR

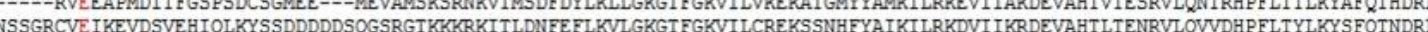
----RQEEFRMNCSPTSQIDNIGEFE---MDASTTHHK-RKTMIDFDYLKL LGKGTFGKVILVREKASGKYYAMKTLKKEVIIAKDEVAHTLTESRVLKNTRHPFLTSLKYSFOTKDR ----RQFEFRMNCSPTSQIDNIGEFE---MDASTTHHK-RKTMIDFDYLKLLGKGTFGKVILVREKASGKYYAMKTLKKEVITAKDEVAHTLTESRVL KITRHPFLTSLKYSFOTKDR

NSSGRR2EEERM2CSPTSQIDN2GEEEDDSMDASTT2HK22KTMNDFDYLKLLGKGTFGKVILVREKASGKYYAMKIL2KEVIIAKDEVAHTLTESRVL2NTRHPFLTSLKYSFQTKDRI

Cgigas

Ssalar2

Glateralis

Hsapiens3

Mputorius3

Prim.cons.

$\begin{array}{rrrrrrrrrrr}250 & 260 & 270 & 280 & 290 & 300 & 310 & 320 & 330 & 340 & 350 \\ 1 & 1 & 1 & 1 & 1 & 1 & 1 & 1 & 1 & 1 & 1\end{array}$

CFVMEYANGGELFFHLSRDRVFTEDRARFYGAE IVSALEYLHSRDVVYRDLKLENLMLDKDGHIKITDFGLCKEGITDGATMKT FCGTPEYLAPEVLEDNDYGRAVDWWGLGVMYEMMC CFVMEYVNGGELFFHLNQERIFPEERARFYGAEICLALGYLHERNIIYRDLKLENLLLDADGHIKIADEGLCKEDISYGSTIRTFCGTPEYLAPEVLEENDYGRGVDWWGYGVCLYEMM CFVMEYVNGGELFFHLSRERVFSEDRTRFYGAEIVSALDYLHSGKIVYRDLKLENLMRDKDGHIKITDFGLCKEGITDAATMKTFCGTPEYLAPEVLEDNDYGRAVDWWGLGVMYEMMC CFVMEYVNGGELFFHLSRERVFSEDRTRFYGAEIVSALDYLHSGKIVYRDLKLENLMLDKDGHIKITDFGLCKEGITDAATMKT FCGTPEYLAPEVLEDNDYGRAVDWWGLGVMYEMMC

CFVMEYVNGGELFFHLSRERVFSEDR2RFYGAEIVSALDYLHS2KIVYRDLKLENLMLDKDGHIKITDFGLCKEGITD2ATMKTFCGTPEYLAPEVLEDNDYGRAVDWWGLGVVYYEMYC

370

$\begin{array}{rrrr}380 & 390 & 400 & 410 \\ 1 & 1 & 1\end{array}$

Cgigas

Ssalar2

Glateralis

Hsapiens3

Vputoriugs

Prim.cons.

GRLPFYNQDHERLFELILVEEIRFPKNLAPEAKALLAGLLKKDPKQRLGGGQEDAKDVMTQKFFISINWQDVVERKLLPPFKPQVISETDTRYFDDEFTAQTITVIPPDKYDSLDSEDQN GRLPFYDKDHDKLFQLTVCEDVRFPRT ISQEARDLLKGLLHKDPNKRLGGGPGDVEEVQSHPFYIT INWKLLEEKKLT PPFKPQVISETDTRYFDREFTGESVQLT PPDQVEHLNSIAEE GRLPFYNQDHEKLFELILMEDIKFPRTLSSDAKSLLSGLLIKDPNKRLGGGPDDAKE IMRHSFFSGVIWQDVYDKKLVPPFKPQVISETDTRYFDEEFTAQIITITPPEKCQQSDCGMLC GRLPFYNQDHEKLFELILMEDIKF PRTLSSDAKSLLSGLLIKDPNKRLGGGPDAKE IMRHSFFSGVWWDVYDKKLVPPFKPOVISETDTRYFDEEFTAQTITITPPEKYDEDGMDCVD

GRLPFYNQDHEKLFELILMEDI2FPRTLSS2AKSLLSGLLIKDPNKRLGGGPDDAKE2MRHSFF2G2NWQDVY2KKLVPPFKPQVISETDTRYFDEEFTAQTITITPP2KYD4LDS4 444

490

Cgigas

Ssalar2

Glateralis

Hsapiens3

Mputorius3

QR-THFPQFSYSASIRE

SENAAFNQFSY-.---

$\mathrm{NWW}-\mathrm{KR}$

NE-R-

Prim.cons. NEN43F2QFSYSASIRE 
Figure 4: Levels of truncated AMPKa protein quantified on western blot (expressed in relative $\mathrm{OD} / \mathrm{mm}^{2}$ ); for different oyster tissues sampled in wild oysters at the sea shore : mantle edge, digestive gland, mantle, labial palps, smooth muscle, striated muscle, heart, gills and visceral ganglia during sexual resting stage $(n=4)$. The protein values presented on the graph were calculated from 4 blots and a representative western blot of truncated AMPKa is shown under the graph. Columns and bars show mean \pm SD. Different letters indicate a significant difference between tissues $(P<0.05)$.

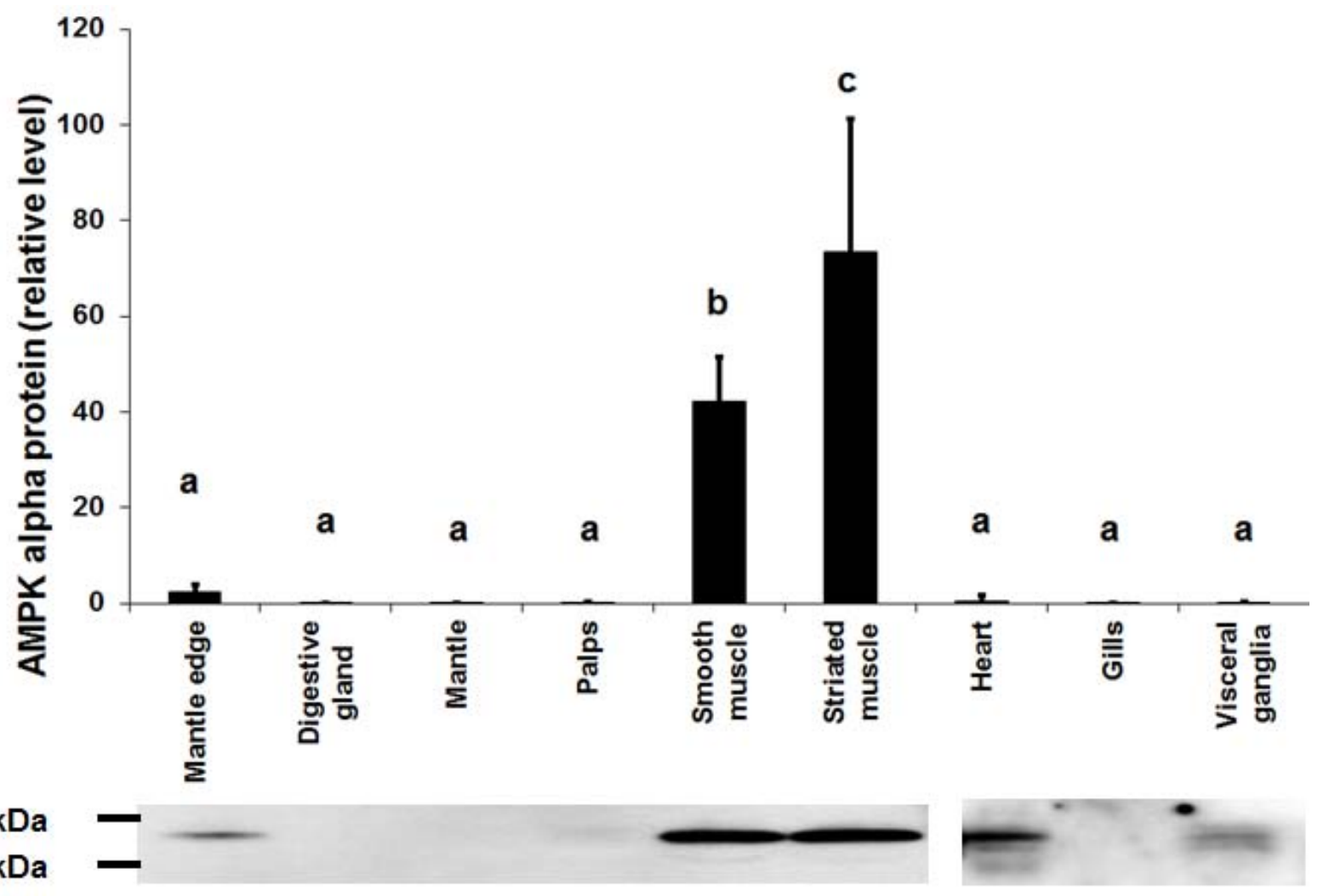


Figure 5: Western-blot of entire AMPKa and truncated AMPKa protein in smooth and striated muscle of oysters exposed to normoxia $(n=4)$ or hypoxia $(n=4)$ measured after 1,3 and $6 \mathrm{~h}$ of challenge. (A) Representative images of entire AMPKa detection at $62 \mathrm{kDa}$ and truncated AMPKa at $46-48 \mathrm{kDa}$. (B) Quantification of truncated AMPKa protein during normoxia (white bars; $n=4$ ) or hypoxia (black bars; $n=4$ ) in smooth muscle. (C) Quantification of truncated AMPKa protein during normoxia (white bars; $n=4$ ) or hypoxia (black bars; $n=4$ ) in striated muscle. The protein values presented on the graph were quantified on 4 western blots and expressed in relative level of OD/mm2. Columns and bars show mean \pm SD. Asterisks indicate a significant difference between conditions $(P<0.05)$.

Smooth muscle

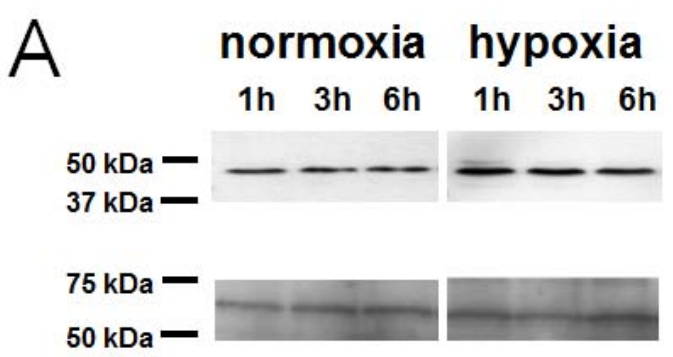

\section{Striated muscle}

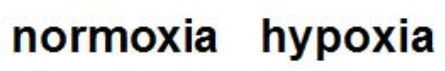

1h $3 \mathrm{~h} \quad 6 \mathrm{~h}$ 1h $3 \mathrm{~h} \quad 6 \mathrm{~h}$

Truncated $50 \mathrm{kDa}-$

AMPKa $37 \mathrm{kDa}-$

$\begin{array}{cl}\text { Entire } & 75 \mathrm{kDa}- \\ \text { AMPKa } & 50 \mathrm{kDa}-\end{array}$

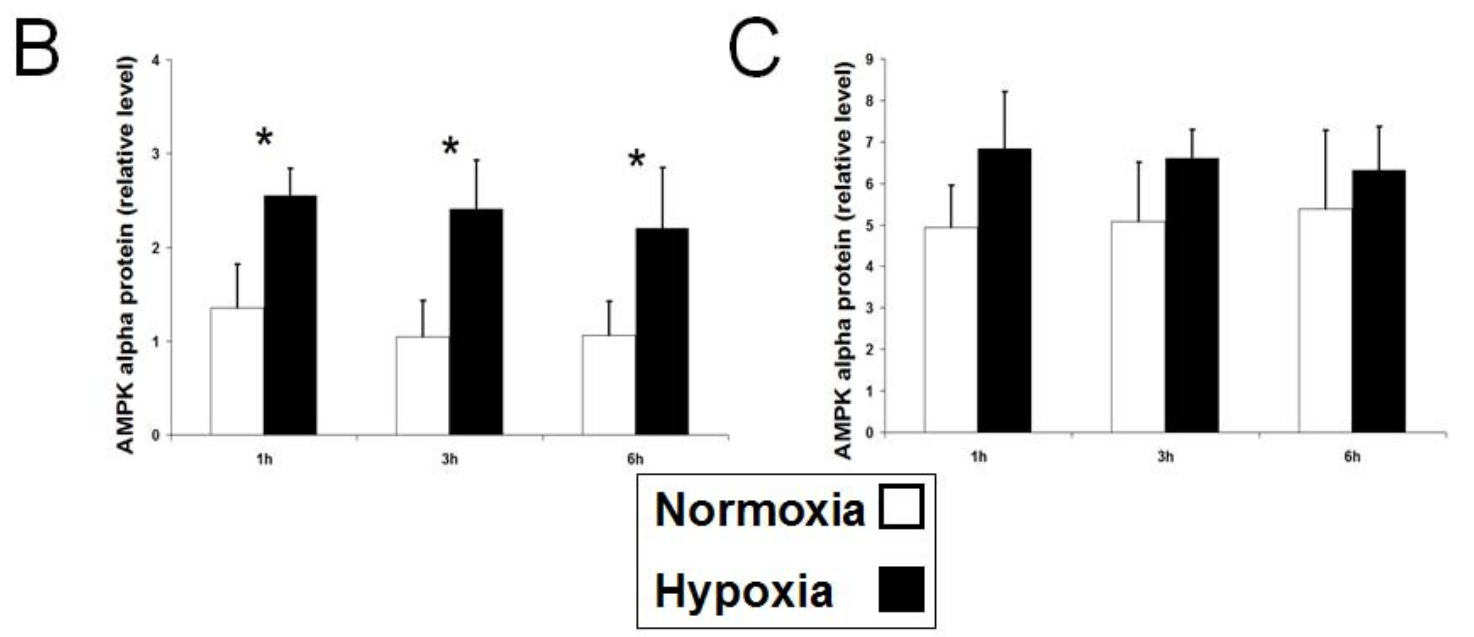


Figure 6: Enzymatic assay of citrate synthase in smooth and striated muscle of oysters exposed to normoxia $(n=4)$ or hypoxia $(n=4)$ measured after 1,3 and 6 h of challenge. $(A)$ Citrate synthase activity during normoxia (white bars; $n=4$ ) or hypoxia (black bars; $n=4$ ) in smooth muscle; (B) Citrate synthase activity during normoxia (white bars; $n=4$ ) or hypoxia (black bars; $n=4$ ) in striated muscle. Different letters indicate significant differences along the temporal sampling $(P<0.05)$. Asterisks indicate significant differences between conditions $(P<0.05)$.

A Smooth muscle

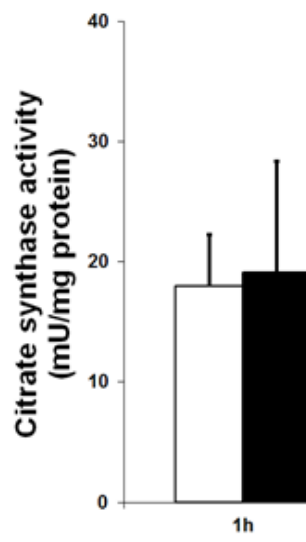

B Striated muscle

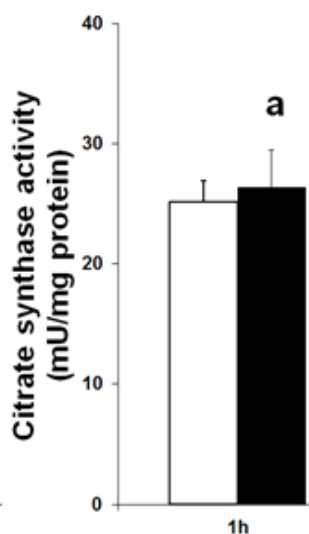

*

a

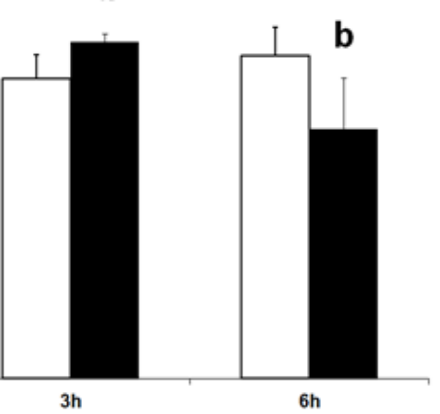


Figure 7: Western-blot of AKT protein in smooth and striated muscle of oysters exposed to normoxia $(n=4)$ or hypoxia $(n=4)$ measured after 1,3 and $6 h$ of challenge. (A) Quantification of AKT protein during normoxia (white bars; $n=4$ ) or hypoxia (black bars; $n=$ 4) in smooth muscle. (B) (A) Quantification of AKT protein during normoxia (white bars; $n=$ 4) or hypoxia (black bars; $n=4$ ) in striated muscle. The protein values presented on the graph were calculated from 4 blots and a representative western blot of truncated AMPKa is shown under the graph. Columns and bars show mean \pm SD. Asterisks indicate significant differences between conditions $(P<0.05)$.
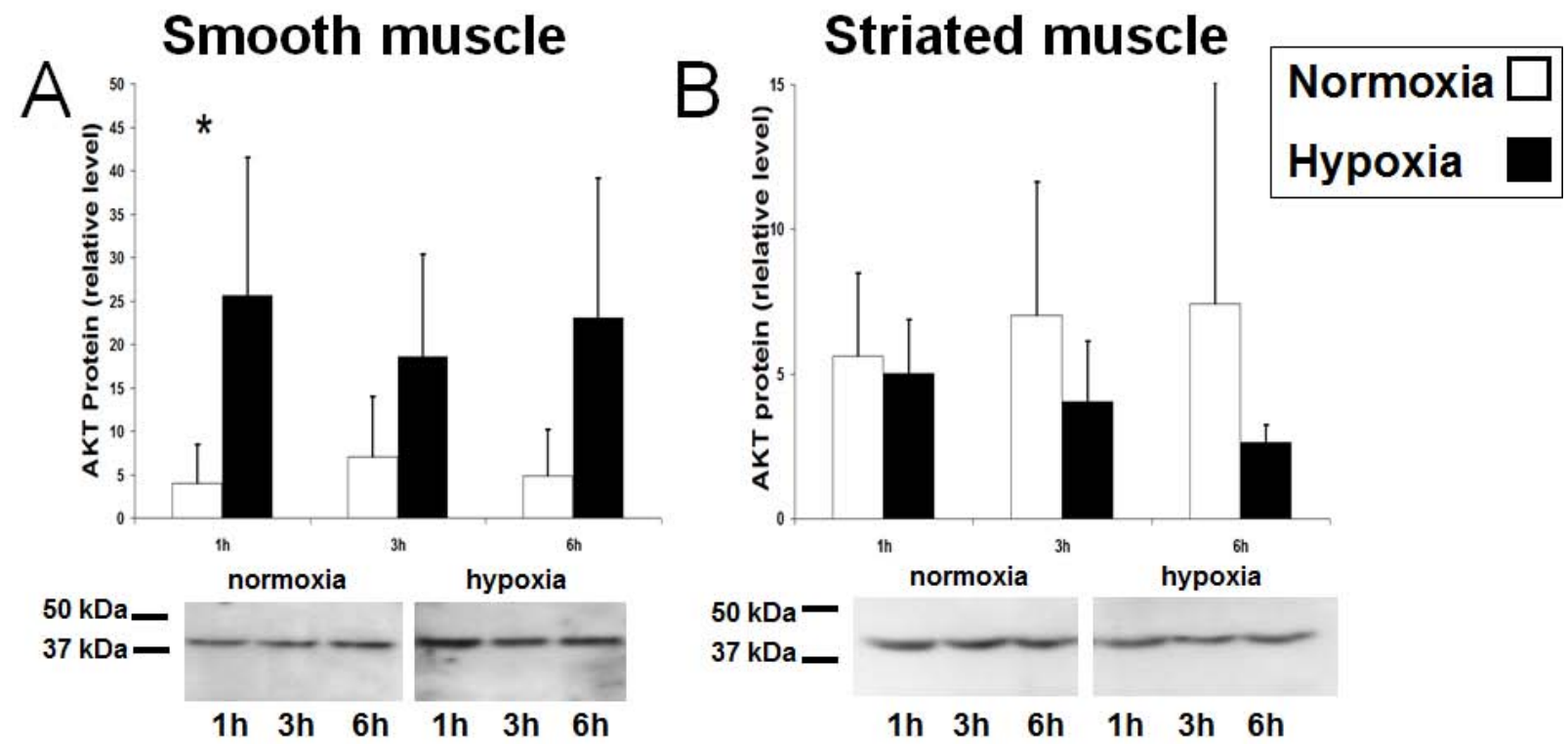